\section{Reactive pleural effusion}

Mihajlović Miloš

Department of Pathology, General Hospital Krusevac, Serbia

\section{Abstract}

The presence of free fluid in the pleural space can be a sign of many pathological processes. Some of them may be of inflammatory or hemodynamic origin but others are caused by a malignant neoplasm spreading either in the pleural cavity or from distant site. The importance of establishing the origin of the cells in the pleural fliud lies not only in the fact that a correct diagnosis leads to a correct therapy, but it also is essential in the staging of a malignant tumor. The aims of this study were to evaluate the frequency of various types of pleural effusion and to discuss the value of reactive atypia of mesothelial cells in longstanding effusions. The introduction of a third cathegory of pleural effusion called reactive, would be helpful to the general pathologists to avoid making false-positive diagnosis in the presence of atypical reactive mesothelial cells or missing the diagnosis of a malignant effusion in case when malignant cells are scarse or look like an activated mesothelial cell. In this study, a total of 157 patients from the thoracic department of the General Hospital in Kruševac were examined. Of this number, 33 patients or $21 \%$ had the so-called reactive type of pleural effusion. In the everyday practice, one in five patients could be expected to have reactive mesothelial atypia, which may be quite confusing in inexperienced hands.

Key words: pleural effusion, cytology, reactive mesothelial cells.

\section{Reaktivna pleuralna efuzija}

\author{
Mihajlović Miloš \\ Odeljenje za patologiju, Opšta bolnica Kruševac, Srbija
}

\section{Apstrakt}

Prisustvo pleuralne tečnosti može biti znak mnogih patoloških procesa. Nekada je posledica inflamatornog ili hemodinamskog poremećaja, ali često je posledica maligne neoplazme koja se širi ili iz pleuralnog prostora ili sa udaljenih mesta. Značaj određivanja porekla ćelija u pleuralnoj tečnosti je važno, ne samo zato što tačna dijagnoza daje tačnu terapiju, već i zbog tačnog određivanja gradusa malignog tumora. Ciljevi ove studije su bili da procene učestalost različitih tipova pleuralnih izliva i značaj reaktivne atipije mezotelnih ćelija kod dugogodišnjih izliva. Uvođenje treće kategorije pleuralnog izliva koji bi se zvao reaktivnim, mogla bi biti od pomoći patolozima, da izbegnu davanje lažno-pozitivnih dijagnoza zbog prisustva atipičnih, reaktivnih, mezotelnih ćelija ili čak izostanak dijagnoze malignog izliva zbog oskudnih malignih ćelija ili njihove sličnosti sa reaktivnim mezotelnim ćelijama. U ovoj studiji je ispitano ukupno 157 pacijenata sa grudnog odeljenja Opšte bolnice u Kruševcu. Od tog broja, 33 pacijenta ili $21 \%$ su imali takozvani reaktivni pleuralni izliv. U svakodnevnoj praksi, kod jednog od pet pacijenata može se očekivati reaktivna mezotelna atipija, što u neiskusnim rukama može stvoriti zabunu.

Ključne reči: pleuralni izliv, citologija, reaktivne mezotelne ćelije

\title{
Introduction
}

The organs of the body cavities are surrounded by thin double layers od mesothelial cells called the serous membranes. The layer that is in intimate contact with the surface of the organs is the visceral while the outer layer is known as parietal layer. Those two membranes are continuous with each other and they form an indipendent space, totally separated from the environment. Three body cavities surrounded by serous membranes can be recognized: the pleural cavity (containing lungs), peritoneal cavity (encloses the intestinal tract) and pericardium (that wraps the heart). The mesothelial cells of the serous membranes are flat cells arranged in a single layer with its connective tissue support and its own vascular and nervous apparatus. The luminal surface of mesothelial cells exibit a gentle brush border which can be sometimes observed in well prepared slides. Mesothelial cells regulate the production of a small ammount of fluid that is found between the two layers of the serous membrane. Under normal cirumstances, the serous membranes space is virtual, in pathologic conditions however, it can be of great volume, containing several litres of liqiud. 
Studied with TEM (transmisson electron microscopy), the mesothelial cells exibit short microvili. If the microvili become visible by light microscopy, it usually indicates a pathological process ${ }^{1,4}$.

The presence of visible fluid, between the serous membranes is considered a priori a pathological finding. Pleural effusions that result from blood serum filtration across an intact endothelial membrane are caused by reduced intravascular osmotic pressure (hypoproteinemia) or increased filtration pressure (heart failure) and are called transudates. Their caracteristics include low protein content and low specific gravity. The cells that can be observed in a transudate are few mesothelial cells and leukocytes.

The main cause of exudate acumulation is damage to the vascular wall and subsequent leakage of fluid in the environment. The exudate colour can vary from opacque to reddish, the latter indicating primary or metastatic tumors or tuberculosis. The protein content of exudates is high, and so is the speific gravity. Because of the presence of fibrin, exudates can coagulate on standing 1,2,3,4. The cell population in exudates can be various, depending on the condition that caused the fluid to fill the serous space. Exudation of fluid from the blood vessel can be caused by inflammatory conditions of near and distant organs, by primary and metastatic tumors or by other reasons ${ }^{4}$.

When an effusion specimen is obtained, it is firstly centrifuged, smeared, fixed and stained either by Papanicolau or MGG methods. Modern procedures require that the rest of the specimen need to be processed as cell blocks for additional special methods or immunostained. In the preliminary assesment of an effusion it is of extreme importance to classify the finding as benign, reactive or malignant (primary or secundary malignant neoplasm). Fluids with low protein content and signs of inflammation are with a high probabity benign. If the cell number rises and the effusion is classified as exudate, care should be taken in differenciation between a reactive and a clearly malignant picture. There are several conditions that can cause reactive atypia in mesothelial cells, like congestive heart failure, pulmonary infarction, pancreatitis, colagen vascular diseases and other ${ }^{4,8}$. Differential diagnosis of such atypical cells is metastatic adenocarcinoma and mesothelioma ${ }^{9}$. In the so-called reactive serous effusion, besides mesothelial cells, there are lymphcytes and macrophages, so another diagnostic problem could be differentiating a benign condition from malignant lymphoma ${ }^{8}$.

Cytology of serous effusions can sometimes by the only diagnostic tool in assesment of malignant tumor spread. Evaluating of cells in a pleural effusion, for exemple, can be essential in staging of a lung tumor ${ }^{10,13}$. The simplicity of the procedure and its benefits cannot be overemphasized.

The aims of this study were to evalute the caracteristic morfologic appearence of benign, reactive and malignant pleural effusions and to discuss the pitfalls of reactive effusion diagnostics.

\section{Matherial and methods}

In this retrospective study, matherial obtained from 157 patients treated in the thoracic department of the Kruševac General hospital was evaluated. The specimen were obtained by pleural punction and transported to the pathology laboratory. The recived specimen were centrifuged on $600 \mathrm{rpm}$ for 10 minutes in $15 \mathrm{ml}$ testtubes. In cases of hemorrhagic serous fluid, a $20 \%$ solution of sodium-citrate that served as anticoagulant was added. In such manner, two fractions of liquid were obtained: an upper, clear and abboundant supernatant that was decanted and a less voluminous, dence precipitate. The latter was smeared on a slide, fixated in $95 \%$ ethanol and stained by H\&E. Two slides taken from each patients were air- dried and stained with the Romanovski stain.

The obtained pleural effusions were classified in three groups as benign, reactive and malignant. Patients epidemiologic caracteristics were analysed and compared with the presence of a particular pleural effusion group. This data were displayed in tables, using apsolute and relative numbers. The relations between these parameters were analyzed with the variability measures, the interval variations and the standard deviation. The X2 nonparametric test was used for hypothesis testing. The data were processed with the SPSS software and the grafics were made in Microsoft office, Excel and Microsoft Powerpoint. 


\section{ORIGINALNI RADOVI}

\section{Results}

In this study, 157 patients underwent pleural cavity exploration during a period of two years (january of 2008 to december of 2009). The evacuation of pleural effusions was performed for diagnostic and therapeutic purposes. The matherial obtained was sent to cytologic, bacteriologic and biochemical evaluation. In evacuation of smaller amounts of fluid a $20 \mathrm{ccm}$ syringe was used while larger collection of fluid were obtained by vacum pump. The main indications for a pleural tap were dispnea, results of physical exams and radiographic confirmation of pleural effusion, obtained by classic PA chest X ray and CT imaging. The majority of patients underwent one pleural punction but a smaller number of participants had repeated taps for therapeutical purposes. Only the first specimen of each patient was taken in consideration, because the cellular matherial in repeated aspirations may be slightly transformed due to the consequences of the previous procedures.

A total of 157 patients was analysed, $53,5 \%$ (84 of 157 ) were males and $46,5 \%$ ( 73 of 157) females (Figure 1).
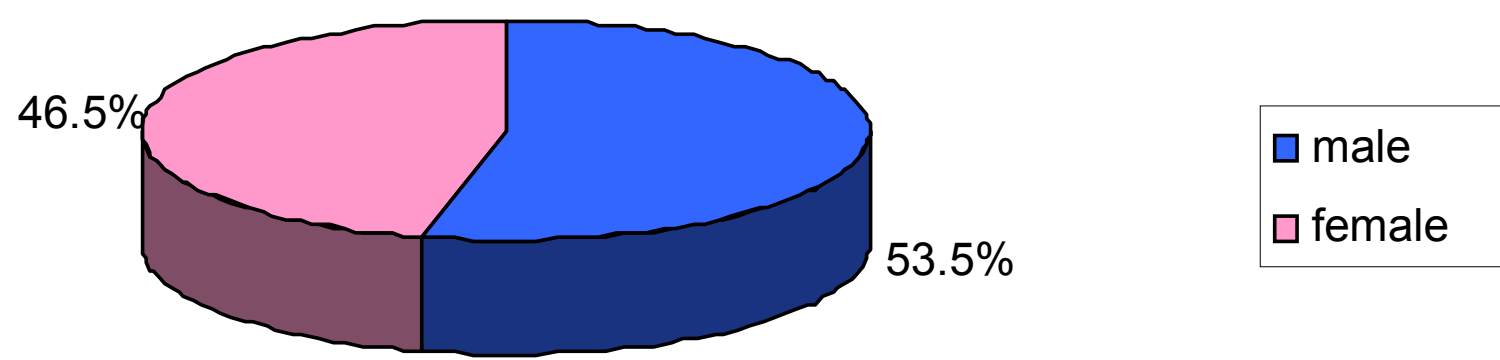

Figure 1. Sex distribution of patients

The mean age of the patients was 64,9+/- 10,4 years. Men were in average 63,2 +/- 10, 6 years old and women were slightly older $(66.9+/-10,0$ years old). The great majority of patients were older than 50 years (142 of 157 or $90,5 \%)$. The age interval with the greatest number of units of analysis was between 70 and 74 years (37 patients of 157 or $23,6 \%$ ) (Table 1.).

\begin{tabular}{|c|c|c|}
\hline Age group & Number & Percent\% \\
\hline $35-39$ & 2 & 1,3 \\
\hline $40-44$ & 4 & 2,5 \\
\hline $45-49$ & 9 & 5,7 \\
\hline $50-54$ & 13 & 8,3 \\
\hline $55-59$ & 23 & 14,6 \\
\hline $60-64$ & 19 & 12,1 \\
\hline $65-69$ & 18 & 11,5 \\
\hline $70-74$ & 37 & 23,6 \\
\hline $75-80$ & 32 & 20,4 \\
\hline Total & 157 & 100,0 \\
\hline
\end{tabular}

Table 1. Age distribution 
Most of the 157 patients were retired from work (106 of 157 or 67,5\%), occupationaly active both workers or farmers were 37 patients $(23,6 \%)$ (Table 2.).

\begin{tabular}{|c|c|c|}
\hline Occupation & Number & Percent $\%$ \\
\hline Worker & 23 & 14,7 \\
\hline Farmer & 14 & 8,9 \\
\hline Unemployed & 14 & 8,9 \\
\hline Retired & 106 & 67,5 \\
\hline Total & 157 & 100,0 \\
\hline
\end{tabular}

Table 2. Occupation distribution

Samples taken from the patients were thoruoghly analysed, described in written form and beside the definitive diagnosis, classified as benign, reative or malignant. The benign group of effusion had undoubtful morfologic signs of acute inflammation or evidence of circulation or osmotic disbalance (hemosiderin ladden macrophages). In the reactive pleural effusion group there was various number of mesothelial cells (single or in small groups), lymphocytes and cells of monocyte-macrophage lineage. The malignant effusions presented different types of cells, depending on the primary or secondary pleural involvment, along with numerous erythrocytes and lymphoplasmocytes. Although all specimen were thoroughly analyzed, special attention was given to the reative pleural effusion group. A total of 33 cases of reactive pattern was diagnosed ( $21 \%$ of 157 patients ). Most of the cases of effusion were in the benign group (104 of 157 of cases or $66,2 \%$ ) (Table 3.).

\begin{tabular}{|c|c|c|}
\hline Diagnosis & Number & Percent \\
\hline Benign & 104 & 66,2 \\
\hline Reactive & 33 & 21,0 \\
\hline Malignant & 20 & 12,8 \\
\hline Total & 157 & 100,0 \\
\hline
\end{tabular}

Table 3. Distribution of benign, reactive and malignant effusions

In relation with the sex distribution of various groups of pleural effusion, there is no statisticaly significant difference $(p>0,05)$ (Table 4.).

\begin{tabular}{|c|c|c|c|c|}
\hline \multirow{2}{*}{ Sex } & \multicolumn{3}{|c|}{ Diagnosis } & \multirow{2}{*}{ Total } \\
\cline { 2 - 4 } & Benign & Reactive & Malignant & \\
\hline Male & 56 & 18 & 10 & 84 \\
\hline Female & 48 & 15 & 10 & 73 \\
\hline Total & 104 & 33 & 20 & 157 \\
\hline
\end{tabular}

Table 4. Distribution of cases in relation with sex and diagnosis of effusions $\chi^{2}=0,118 ; \mathrm{df}=3 ; \mathrm{p}>0.05$;

There is no significant difference between the various age group and the distribution of pleural effusion groups, either (Table 5.). 


\section{ORIGINALNI RADOVI}

\begin{tabular}{|c|c|c|c|c|}
\hline \multirow{2}{*}{ Age } & \multicolumn{3}{|c|}{ Diagnosis } & \multirow{2}{*}{ Total } \\
\cline { 2 - 4 } & Benign & Reactive & Malignant & 2 \\
\hline $35-39$ & 1 & 1 & 0 & 4 \\
\hline $40-44$ & 3 & 1 & 0 & 9 \\
\hline $45-49$ & 5 & 2 & 2 & 13 \\
\hline $50-54$ & 8 & 3 & 2 & 23 \\
\hline $55-59$ & 13 & 7 & 3 & 19 \\
\hline $60-64$ & 8 & 7 & 4 & 18 \\
\hline $65-69$ & 14 & 3 & 1 & 37 \\
\hline $70-74$ & 27 & 6 & 4 & 32 \\
\hline $75-80$ & 25 & 3 & 4 & 157 \\
\hline Total & 104 & 33 & 20 & \\
\hline
\end{tabular}

Table 5. Distribution of cases in relation with age and diagnosis

\section{Discussion}

The presence of free fluid in the pleural space can be caused by imbalance of the capillary dynamics and impaired osmotic pressure when it presents as a transudate. When the integrity of the capillary membrane is compromised, as it happens in inflammatory or malignant processes, the pleural space fills with exudate. The greatest number of patients seek medical help when dispnea becomes prominent ${ }^{1}$. Those patients may already have a diagnosis of acute or chronic lung or pleural disease, but effusions sometimes are the first sign of lung involvment. Since the simptoms of pleural effusion depend on the amount of fliud and the underlinig process, the role of the clinician is not only in relieving the patients trouble but also in establishing the correct diagnosis ${ }^{2,4}$. Data from the available literature suggest that all pleural effusion can be separated in two cathegories: those without malignant cell (benign effusions) and effusion with the presence of malignant cells (malignant effusions) ${ }^{1}$. As one of the aims of this study, the presence of a third group of reactive pleural effusions has been described. Although there are no statistical tests for examination of this group, we consider the use of suh classification to be a valuable tool in assesing false-negative effusions. In our study group, 33 of 157 patients or $21 \%$ had reactive pleural effusions, a fact that cannot be overlooked. Most of the patients in this group had long lasting simptoms and were not treated invasivly for a certain period of time. This fact contributed to the appearence of atypical reactive mesothelial cells, numerous erythrocytes and marophages with altered nucleocytoplasmic ratio. The detailed analysis of such effusions helped us to avoid assesing benign effusions as false-positive and some incipient malignant effusions with a few malignant cells as false-negative. We were able to direct the search for an incipient malignant neoplasm in cases that otherwise would have been conluded as benign, and prevent the loss of valuable time in starting the correct therapy. Motherby et al. reported the rate of false-negative results of pleural effusion cytology which was due to sampling or screening errors ${ }^{5}$. Since in our study we evaluated the possibility of screening errors, we could say that a cathegory of reactive effusions may be helpful i avoiding such errors.

A study evaluating 3811 patients with one or repeated pleural fliud aspiration reported a cytopathologic correlation accuracy of $96,5 \%, 0,1 \%$ of false-positive and $0,18 \%$ of false-negative cytologic results ${ }^{6}$. In the same study, the sensitivity of effusion cytology was $6,7 \%$ higher than that of the pleural biopsy. This demonstrates that cytologic examination of the pleural space can sometimes be more valuable than even the pleural biopsy ${ }^{12}$. At this point, it must be stated that pleural involvment of both benign and malignant processes can be focal, thus biopsy results bring just one of many pathohistologic pictures of the same case ${ }^{10,11,12}$. The importance of avoiding false-negative results lies in the fact that if therapy in cases with unrecognized malignant tumor is delayed the survival rate of these patients can be severly compromised.Sujathan and collegues have 
reported that some plant lecitin can be used to distinguish reactive mesothelial cells in benign and malignant effusion ${ }^{7}$. Further study are needed in this field but help should be expected from markers that would stain intensivly mesothelial cells in malignant effusion. In our study, there were no stytistically significant difference in pleural effusion presence as well as presence of different types of effusion between males and females. This is concordant with the data found in the literature ${ }^{6}$. The same lack of significance can be found if the relation between age distribution and effusion is observed. Although effusions are often seen in older patients, according to the previously stated data the frequency of effusions can be expected in every age group.

Diagnostic pleural cytology is a low-cost, fast method that can give answer to most of the clinicians questions, one of them may be whether a longstanding effusion is either reactive or malignant. In skilled hands, this procedure can be be of extreme value for both the patient and his doctor. A group of reactive effusion could be helpful to general pathologists who participate in diagnostic assesment of such patients.

\section{Literature}

1. Cibas ES. Ducatman BS. Cytology Diagnostic Principles and Clinical Correlates. Saunders. 3rd edition. 2009.

2. Erozan SY, Ramzy I. Pulmonary Cytopathology. Springer. 2009.

3. Bibbo M, Wilbur DC. Comprehensive Cytopathology. Saunders. 3rd edition. 2008.

4. Koss LG, Melamed MR. Diagnostic Cytology and its histopathologic bases. Lippincot Williams \&Wilkins.5th edition. 2006.

5. Motherby H, Nadjari B, Friegel P, Kohaus J, Ramp U, Bocking A. Diagnostic accuracy of effusion cytology. Diagnostic ytopathology 1999;20(6): 350-357;

6. Hsu C. Cytologic detection of malignancy in pleural effusion: A rewiew of 5,225 from 3811 patients. Diagnostic cytopathology 1987;3(1):8-12.

7. Sujathan K, Pillai KR, Amma NS, Chandraleka B, Kannan S, Remani P, Kirshnan Nair M. Differential expression of jackfruit-specific gylcoconjugate in metastatic adenocarcinoma and reactive mesothelial cells-a diagnostic aid in effusion cytology. J Cancer Res Clin Oncol 1996;122: 433-436.

8. Davidson B. Firat P. Michael CW. Serous effusion. Etiology, diagnosis, prognosis and therapy. Springer. 2012.

9. Liht RW. Pleural effusions. Med Clin North Am. 1997; 61(6): 1339-52.

10. Dines DE. Pierre RV. Franzen SJ. The value of cells in the pleural fluid in the differential diagnosis. Mayo Clin Proc1975 Oct;50(10):571-2.

11. Pereira TC. Saad RS. Liu Y. The diagnosis of malignancy in effusion cytology: a pattern recognition approach. Advances in anatomic pathology. 2006;13(4):174-184.

12. Salyer WR. Egglestone JC. Erozan YS. Efficacy of pleural needle biopsy and pleural fluid cytopathology in the diagnosis of malignant neoplasm involving the pleura. Chest May 1975; 67(5):536-539.

13. US-Canadian. Mesothelioma Reference panel: Churg A., Colby T., Cagle P. et al. The separation of benign and malignant mesothelial proliferation. Amer J Surg Pathol. September 2000; 24(9):1183-1200.

Primljen 18. XI 2011.

Revidiran 6. I 2012.

Prihvaćen 28. I 2012.

Autor za korespondenciju:

Dr Miloš Mihailović

Zdravstveni centar Kruševac

tel. +381 037/ 414-000, 421-826, 424-043

e-mail: milosmihajlovic64@gmail.com

mob. tel:063 621389 